\title{
Processes of Early State Development. A Review Article
}

\author{
ROBERT WUTHNOW
}

\author{
Princeton University
}

Burmese Administrative Cycles: Anarchy and Conquest, c. 1580-1760, by Victor B. Lieberman (Princeton: Princeton University Press, 1984).

The Sultan's Servants: The Transformation of Ottoman Provincial Government, 1550 1650, by I. Metin Kunt (New York: Columbia University Press, 1983).

Politics and Society in Early Modern Iraq: Mamluk Pashas, Tribal Shayks and Local Rule Between 1802 and 1831, by Tom Nieuwenhuis (The Hague: Martinus Nijhoff, 1981).

Traditional Government in Imperial China: A Critical Analysis, by Ch'ien $\mathrm{Mu}$, translated by Chun-tu Hsueh and George O. Totten (Hong Kong: Chinese University Press, 1982).

State and Society in Dar Fur, by R. S. O'Fahey (New York: St. Martin's Press, 1980).

An earlier generation of studies which portrayed political development as a continuous, generalizable process has largely been superseded. The more recent generation of work has taken a more limited approach, focusing narrowly on processes of European state building rather than attempting to generalize beyond the European case. These studies have emphasized such prototypical European problems as the rise of absolutism, differences in the effects of feudal development between eastern and western Europe, and the transition from standestadten to centralized bureaucracies. Whether any of these processes have generality beyond Europe has remained an open question.

The books under consideration here provide, collectively, an opportunity to assess the generality of recent political development models for non-European cases. None of the cases with which they deal falls within the context of usual European-based discussions. Ranging from Burma and China, to the Ottoman Empire and Iraq, to the Sudan, these studies encompass cases that differ radically in prehistory, culture, and political trajectory. When read together, they offer an unusual glimpse of the diversity of paths along which political development has progressed. 
Each of the five books is quite different from the others, not only in choice of subject matter but also in scope and intended purpose. Lieberman's study of Burmese administrative cycles is in some ways the most ambitious. Covering almost two centuries during the critical period of Burma's "early modern' development, it chronicles much of the important political history of this period and analyzes a relatively broad list of topics dealing with the nature of political rule. Kunt's book on the transformation of Ottoman provincial government between 1550 and 1650 has a much more limited focus. Drawing on prosopographic data for several hundred provincial governors during this period, it considers quantitatively several questions about the recruitment, promotion, and conditions of service of Ottoman officials. The monograph by Nieuwenhaus on politics in early modern Iraq shifts attention from Ottoman rule at the core of its empire to one of the more interesting regions at the fringe of this empire. Iraq, during the early part of the nineteenth century, remained formally a part of the Ottoman empire, but its local officials retained a great deal of autonomy from the central regime, thus giving them an opportunity to develop political structures that in certain respects, resembled those in fully autonomous states. Mu's book on China, in contrast to the others, does not focus on a single period of political development but surveys the character of administrative systems at different periods in China's history. Beginning with the Han dynasty in 200 B.C. and extending through the Ch'ing dynasty, which ended in 1911, the chapters of the book systematically examine the organization of government, the character of the civil service, the tax structure, and the military system for each of China's major dynasties. O'Fahey's study of the Dar Fur sultanate in the Sudan, finally, deals with political development mainly from the 1750 s to 1916 in an area that was partially under Muslim rule but in most other ways differed from those considered either by Kunt or Nieuwenhuis. Based on an extensive collection of official correspondence from this period, the book focuses mainly on the evolution of the central administrative structure but also traces some of the broader social and economic changes that conditioned this development. It perhaps goes without saying, therefore, that the five books do not lend themselves to a complete, point-by-point comparison of the political systems of five nonEuropean societies.

Nevertheless, a number of common themes run through these studies. Each addresses questions about the relations between central government and the prerogatives of provincial elites; each is concerned with certain aspects of the administrative bureaucracy, including questions of staffing and organization; each finds it necessary (although to different degrees) to consider the sources and consequences of factionalism among elites; each pays more than passing attention to the role of the military; and each discusses issues of revenue generation and the uses to which state revenues were put. More generally, the five studies also share a common perspective on the nature of the political development process. 
That perspective emphasizes the uneven, discontinuous, and in some cases, cyclical character of the state-building process. This emphasis is most readily apparent in Lieberman's study, which explicitly conceptualizes Burmese political development between 1580 and 1760 as two successive cycles. These consisted of four distinct phases, including a period of imperial decline in the late sixteenth century, a period of reintegration during the first half of the seventeenth century, another period of decline lasting from the middle of the seventeenth century to the middle of the eighteenth century, followed by another period of centralization. The other studies also demonstrate the unevenness with which political development was characterized and, in some cases, the long periods during which administrative consolidation appeared to be in retrogression. For example, Iraq experienced an exceptionally long period of decline, lasting from roughly the ninth century to the nineteenth century, which was epitomized not only by a weak political structure but by depopulation and faltering resources as well. Dealing with an even longer period, Mu portrays China as moving erratically toward a system of rational institutions during the T'ang dynasty (618-907) but then devolving into systems of expediency, particularly under the Ch'ing dynasty (1644-1911).

For many areas of Europe during the early modern period, the process of state building was by no means linear either, as the decline of Spain and the fragmentation of the Mediterranean basin illustrate. Yet in contrast, the European context was characterized by a relatively high degree of economic and demographic expansion that fueled the engine of political development whereas countries like Burma and Iraq underwent a much more extended path toward an efficient state apparatus.

Despite these obvious differences, the fundamental dynamic of state building in many non-European areas, like those in Europe, revolved around the shifting balance of power between central and provincial elites. In these cases, unlike Europe, the question was less one of absolutism versus representative government as it was of any central regime versus regional fragmentation. When a regime was overthrown, the threat of invasion or anarchy was strong enough that regional elites generally came to support some kind of restoration of the central regime. In Burma this tendency was sufficiently apparent that Lieberman relies on it to suggest a kind of inevitability to the cycles of centralization and decentralization he describes.

Conflict between the central regime and provincial elites also plays a prominent role in O'Fahey's analysis of the Sudan. The central regime, represented by the Dar Fur sultanate, made repeated efforts during the nineteenth century to bring tribal leaders under an effective administrative hierarchy, making particular usage of the familiar strategy of sending loyal administrators from the central bureaucracy to act as overlords in the provinces; but the effectiveness of this strategy was limited by the tendency of these administrators to develop kinship ties with the local elites whom they were supposed to supervise. When the British arrived in 1916, they found a highly entrenched system 
of tribal chiefs who proved nearly impossible to restrain by any broader administrative apparatus.

Lacking a comparative focus, none of the studies attempts to account for the difficulties that many developing regimes experienced in attempting to impose central control over regional elites, as compared to the successes that many of the European regimes experienced during the same period. On the surface, it appears that some explanatory mileage might be gained by paying closer attention to the incentives that different regimes had at their disposal as means of securing compliance from local elites. In the case of Dar Fur, for example, the only incentive readily available to the sultanate was to supply access to lands and herds from which administrators could increase their livelihoods. Thus, it was seemingly likely that administrators should become gradually integrated into the economic and political networks of the provinces themselves. By comparison, many European regimes were able to subvert this process by utilizing the expanded revenues from commerce to build large central bureaucracies capable of reabsorbing provincial elites as a kind of reward for loyal service.

Also of considerable importance in these non-European cases was the lack of any kind of landtag, Estates General, or parliamentary system whereby the interests of various regional factions could be organized. As a result, succession crises or weaknesses at the center tended to devolve into regional strife or provincialism rather than being resolved by some formalized or constitutional process. Moreover, much of the conflict internal to the state that developed in Europe during the eighteenth century came to focus on questions of sovereignty and representation whereas similar conflicts in these cases tended to locate themselves within the royal household or between different administrative bureaus.

Lieberman's study, in particular, stresses the importance of conflicts within the administrative bureaucracy, especially between the monarch and the administrative staff. This conflict resulted in oscillations between periods during which one or the other gained the upper hand. Lieberman again perceives a kind of inevitability to these oscillations, given the inherent contradictions between the monarch's demands for absolute subordination and his actual dependence on the administrative staff. In the Ottoman empire, these contradictions were partially resolved by relying extensively on slaves to fill high administrative posts. Yet, as Kunt observes, this mechanism was only partly successful since many such officials who reached higher levels of prominence were allowed to develop powerful patronage networks. These networks were reinforced by the lack of a more formalized system of ranks, training, and promotions within the bureaucracy, one result of which was to introduce an element of factionalism and instability into the major administrative agencies.

As in the Ottoman sultanate proper, the administrative hierarchy under the pasha of Iraq was staffed chiefly by slaves who had been imported as chil- 
dren, trained at the court, and therefore presumed to be loyal to the person of the ruler himself. The bureaucracy thus remained subordinate to the royal household. Within the bureaucracy itself, however, an increasingly distinct division of labor developed among different offices and departments. Generally, the distinction between military and civil officers was most important while within each differences of rank and status were also clearly delineated. Officials received specialized training in subjects ranging from tax collection to martial arts to diplomacy to literature.

In contrast to the other cases, Ch'ing China provides a picture of relatively successful subordination of the administrative staff to the imperial dynasty. According to Mu's portrayal, the Ch'ing dynasty succeeded in ruling almost in dictatorial fashion by cultivating the self-interests of the Manchu aristocracy. This process required subverting the traditional role of the literati, suppressing freedom of speech, and modifying the civil examination system in such a way that the Manchus were assured prominence in high administrative posts and in the military. Mu traces this system through the difficult period of the nineteenth century, which witnessed an increasing number of popular uprisings against the regime. His analysis, however, fails to consider why the Manchu elite was as successful as it was, what mechanisms were used to secure loyalty within the Manchu elite, and what the relations were between the Manchu elite and other local elites.

While still the subject of much debate, the staffing of administrative agencies with slaves appears, from the studies dealing with Ottoman areas, to have impeded the development of modern state functions less than some literature has suggested. Insofar as slave recruits received specialized training, they appear to have functioned as effectively as many European civil servants during the same period. Indeed, rewards, ranks, promotions, and other kinds of benefits often displayed remarkable similarities between the various systems. More apparent is the relation of slave recruitment to the role of indigenous elites. Whereas European regimes frequently drew valuable resources into the state by incorporating local elites, cases such as Burma and Iraq appear to demonstrate little incentive for local elites to support the state or for the state to draw maximally from cooperative ventures with these elites. Again, differences in rules of succession, parliamentary bodies, and overall economic resources seem important considerations in evaluating the effects of these practices.

These studies also illustrate the vital role that military administration played during the early modern period. Defense against invasion and conquest was one of the few services that a central regime could offer provincial elites in return for some degree of loyalty. The capacity to maintain an effective standing army also served as an instrument of intimidation against potential popular uprisings. Most early modern states accordingly developed various systems of "commands" or "provincial governorships" which gave loyal 
notables the right to collect tribute in return for maintaining a military presence in the region. The chief difficulty in operating these systems was, again, that of maintaining central control over the various provincial armies. Kunt's study examines this problem in considerable detail, showing how it led gradually to a more rationalized system of training and control. Throughout much of the Ottoman empire, provincial governorships came increasingly to be staffed by persons whose careers not only had originated as slaves and who had been trained under the sultanate but also who had proven themselves loyal and responsible through years of service in the central bureaucracy. In a sense, the highest reward for loyal service was to be given charge of an important region in which one's loyalty was especially valued, but also a region in which one could gain wealth and status from tribute.

On most of these points, the present cases, therefore, suggest rather sharp contrasts with European political development. The problems faced, particularly that of imposing central authority on local elites, were sometimes similar to those faced by European state builders; but differences in economic resources, social structure, and cultural norms led to outcomes that generally differed from those attained in Europe.

On one final point some convergence is nevertheless implied, at least in methodological strategy. That is to give greater weight to the role of larger economic and political contexts, as has been attempted for Europe in "worldsystem" approaches. Unfortunately, the present studies focus mainly on domestic issues, only hinting at the importance of broader contexts. One exception that illustrates the importance of considering such broader contexts is a brief argument that Kunt develops concerning the effects on Ottoman political structure of its exposure to the West during the sixteenth century. The two most important aspects of this exposure were military confrontation with the Hapsburgs and inflation resulting from the influx into western Europe of American bullion. The Ottoman response to the Hapsburg military threat was to increase its own army from about 15,000 men to nearly 85,000 . Nearly all of this increase came within the central army, as opposed to the more traditional provincial cavalries, since the latter could not be brought together effectively for drills and training in the use of new weapons. To cover the costs of this expanded military system, the state was forced to shift from its traditional practice of assigning local powers of taxation in return for cavalry service to new policies which would yield cash revenues to the central treasury. The peasantry remained the only source to tax, however, and the increasing tax burden drove rising numbers of peasants off the land into the towns and contributed to the growth of brigandage and rural unrest. These problems were compounded by the general price inflation, which especially hit persons on fixed incomes, namely, the army troops and senior government administrators in the provinces. To supplement their incomes, many senior officials turned to "extracurricular" activities, such as trade and tax collecting, thus 
becoming financially less dependent on the central bureaucracy. The culmination of this process was the eventual emergence of semi-autonomous provincial elites in control of their own economic resources, retinues, and standing armies; many of these elites took part in the major revolt against the central regime which occurred in 1658. Thus, the Ottoman empire's interaction with the West contributed ultimately, albeit by a circuitous route, to a fairly radical restructuring of its relations with provincial patterns of government.

This example, it might also be noted in conclusion, illustrates the value of paying close attention to the economic base on which early political development was built. Not only the sheer availability of resources but also the kinds of institutional arrangements necessary to extract these resources figured as major elements in the state building process. 